\title{
PERSEPSI PETANI PADI TERHADAP PROGRAM BILLING SYSTEM DI KECAMATAN METRO BARAT KOTA METRO
}

\section{PERCEPTION OF RICE FARMERS IN THE BILLING SYSTEM PROGRAM IN METRO BARAT DISTRICT, CITY OF METRO}

\author{
Muher Sukmayanto*, Erika Dwi Alviana, Abdul Muhtholib \\ Jurusan Magister Penyuluhan dan Komunikasi Pertanian \\ Fakultas Pertanian Universitas Lampung,
}

Jl. Prof. Dr. Soemantri Brodjonegoro No.1 Bandar Lampung 35145, Telp. 082178127495

*Corresponding email: muhersukmayanto7@gmail.com

(Diterima 24-11-2018; Disetujui 13-01-2019)

\begin{abstract}
ABSTRAK
Penelitian ini bertujuan untuk mengetahui persepsi petani padi pada program billing system. Penelitian ini dilakukan di Kecamatan Metro Barat, Kota Metro. Pengambilan sampel dalam penelitian ini menggunakan teknik purposive sampling, yaitu petani dari peserta program billing system. Jenis data yang digunakan dalam penelitian ini adalah data primer dan sekunder. Metode yang digunakan dalam penelitian ini adalah metode analisis deskriptif kualitatif yang digunakan untuk menentukan persepsi petani padi terhadap program billing system. Hasil penelitian diperoleh persepsi petani terhadap program billing system dilihat dari tujuan program dalam kategori baik. Persepsi petani terhadap program billing system dilihat dari pelaksanaan program masih dalam kategori kurang baik. Persepsi petani terhadap program billing system dilihat dari manfaat yang diperoleh petani dikategorikan baik.
\end{abstract}

Kata kunci: petani, persepsi, sistem penagihan program

\section{ABSTRACT}

This study aims to determine the perceptions of rice farmers on billing system programs. This research was conducted in Metro Barat District, Metro City. Sampling in this study used a purposive sampling technique, namely farmers from participants in the billing system program. The type of data used in this study are primary and secondary data. The method used in this study is a qualitative descriptive analysis method used to determine rice farmers' perceptions of billing system programs. The results of the study obtained farmers' perceptions of the billing system program seen from the program objectives in the good category. Farmers' perceptions of billing system programs seen from program implementation are still in the poor category. Farmers' perceptions of billing system programs seen from the benefits obtained by farmers are categorized as good.

Key words: farmers, perception, billing sistem program

\section{PENDAHULUAN}

Pupuk merupakan bagian dari faktor produksi dalam usahatani. Pupuk mengandung sejumlah unsur nutrisi yang diperlukan bagi tanaman. Pemberian pupuk pada tanaman akan berpengaruh dalam pengoptimalkan dalam usaha meningkatan hasil produksi. Dewanto (2013) menyatakan pemupukan dengan menggabungkan antara pupuk anorganik dan organik lebih meningkatkan produksi tanaman. Jenis pupuk yang sering dipakai 


\section{PERSEPSI PETANI PADI TERHADAP PROGRAM BILLING SYSTEM \\ DI KECAMATAN METRO BARAT KOTA METRO \\ Muher Sukmayanto, Erika Dwi Alviana, Abdul Muhtholib}

adalah jenis pupuk anorganik/kimia yaitu pupuk hasil proses rekayasa secara kimia, fisik dan atau biologis, dan merupakan hasil industri atau pabrik pembuat pupuk. Akan tetapi ada kendala yang dihadapi petani dalam memperoleh pupuk tersebut. Kendala yang dihadapi petani diantaranya harga yang terlalu mahal sehingga petani sulit untuk membeli pupuk tersebut. Upaya pemerintah dalam merespon hal tersebut yaitu dengan memberikan pupuk subsidi yaitu pupuk yang pengadaan dan penyalurannya mendapat subsidi dari pemerintah dengan harga yang relatif murah untuk kebutuhan petani yang dilaksanakan atas dasar program pemerintah di sektor pertanian.

Pupuk subsidi diatur oleh pemerintah melalui Peraturan Menteri Pertanian No. 06/Permentan/SR.130/2/ 2011 yang isinya bahwa pupuk jenis tertentu tetap mendapatkan subsidi harga, namun terbatas pada kalangan tertentu dan dengan harga eceran tertinggi yang telah ditetapkan. Kalangan tertentu yang dimaksudkan pada Permentan No. 06/Permentan/SR.130/2/2011 pada Bab II tentang peruntukan pupuk bersubsidi pada pasal 2 ayat 1 adalah sebagaimana tertulis: Pupuk bersubsidi diperuntukkan bagi petani, pekebun, yang mengusahakan paling luas 2 (dua) hektar setiap musim tanam per keluarga petani. Pasal 2 tertulis: Pupuk bersubsidi sebagaimana dimaksud pada ayat (1) tidak diperuntukkan bagi perusahaan tanaman pangan, hortikultura, perkebunan.

Perbedaan harga pupuk bersubsidi dan nonsubsidi ini menimbulkan masalah baru bagi petani, yaitu kelangkaan pupuk. Perbedaan harga antara pupuk bersubsidi pada pertanian rakyat dan pupuk nonsubsidi pada pertanian perusahaan besar hal ini akan menimbulkan dorongan bagi para pelaku distribusi pupuk untuk menjual pupuk bersubsidi kepada pengguna pupuk non-subsidi. Akibatnya terjadi kelangkaan pasokan pupuk bagi pengguna yang mendapatkan subsidi pupuk tersebut.

Peraturan Menteri Perdagangan Nomor 15/M-DAG/Per/2015 menetapkan peraturan tentang pengadaan dan penyaluran pupuk bersubsidi untuk sektor pertanian. Pengawasan pupuk bersubsidi dilakukan oleh seluruh instansi terkait yang tergabung dalam Tim Pengawas Pupuk Bersubsidi Tingkat Pusat maupun oleh Komisi Pengawas Pupuk dan Pestisida (KPPP) tingkat provinsi dan kabupaten/kota. Komitmen dan peran aktif pemerintah daerah melalui optimalisasi kinerja KPPP dan Penyidik 
Pegawai Negeri Sipil (PPNS) di provinsi dan kabupaten/kota dalam pengawalan dan pengawasan terhadap penyaluran dan HET pupuk bersubsidi di wilayahnya. Hal ini diharapkan untuk menjamin penyaluran pupuk bersubsidi dapat dilaksanakan sesuai prinsip 6 (enam) tepat (jenis, jumlah, harga, tempat, waktu dan mutu) (Sugiarto, 2017).

Berdasarkan Sahabat Petani (2018), untuk memperbaiki sistem distribusi pupuk bersubsidi, Pemerintah Provinsi Lampung membuat kebijakan billing system. Hal ini merupakan strategi untuk meminimalisir terjadinya distribusi pupuk bersubsidi yang tidak tepat waktu dan tepat sasaran. Adanya billing system diharapkan mampu menyederhanakan prosedur penebusan dan menjamin ketersediaan pupuk bersubsidi sampai kepada yang berhak. Penyaluran pupuk subsidi melalui program billing system dapat diawasi oleh petani, bank, produsen/ distributor, serta pemerintah. Keuntungan dari billing system bagi petani antara lain pupuk yang diterima sesuai dengan prinsip enam tepat, yaitu tepat jumlah, tepat tempat, tepat jenis, tepat harga, tepat mutu, dan tepat waktu (Suara Pedia, 2018).

Kota Metro merupakan salah satu daerah di Provinsi Lampung yang sebagian besar penduduknya bekerja pada sektor pertanian khususnya dalam kegiatan usahatani tanaman pangan padi dan merupakan daerah yang menerapkan program billing system. Program billing system merupakan inovasi program pemerintah untuk membantu petani dalam menyelesaikan masalah terkait pendistribusian pupuk tepat waktu dan sasaran. Program inovasi yang dilakukan pemerintah merupakan program positif yang diperuntukkan untuk sasaran program yaitu petani. Akan tetapi pada kenyataannya program billing system tidak semua petani/kelompok tani beranggapan bahwa program inovasi tersebut diterima/setuju sesuai dengan kemampuan/keadaan wilayah petani. Fachrista dan Sarwedah (2014), menyatakan bahwa inovasi teknologi pertanian yang berhubungan dengan sasaran petani tidak secara langsung diterapkan oleh petani. Keputusan petani untuk mengadopsi suatu inovasi teknologi pertanian dengan sasaran petani sebagai pelaku utama membutuhkan waktu dan persepsi petani akan mempengaruhi tingkat penerimaan keputusan petani dalam mengadopsi inovasi tersebut. Berdasarkan uraian di atas diduga petani padi di Kota Metro memiliki persepsi yang berbeda terhadap 


\section{PERSEPSI PETANI PADI TERHADAP PROGRAM BILLING SYSTEM \\ DI KECAMATAN METRO BARAT KOTA METRO \\ Muher Sukmayanto, Erika Dwi Alviana, Abdul Muhtholib}

program billing system dari kebijakan pemerintah dalam mengadopsi program tersebut. Tujuan dari penelitian ini untuk mengetahui persepsi petani padi terhadap program billing system di Kota Metro.

\section{METODE PENELITIAN}

Penelitian dilakukan di Kecamatan Metro Barat Kota Metro. Pemilihan lokasi penelitian dilakukan secara sengaja (purposive) (Singarimbun dan Effendi,1995) dengan pertimbangan bahwa Kecamatan Metro merupakan kecamatan yang mayoritas petani padi dan merupakan peserta yang melakukan program billing system. Pengambilan sampel dalam penelitian ini menggunakan metode teknik purposive sampling yaitu petani dari peserta program billing system berjumlah 10 orang. Pelaksanaan penelitian yang dilakukan dengan menggunakan teknik survey karena jumlah informan yang diwawancara hanya terdiri atas 9 anggota peserta program billing system dan 1 orang ketua program billing system (Juliandi et al, 2014).

Jenis data yang digunakan dalam penelitian ini yaitu data primer dan sekunder. Data primer diperoleh melalui wawancara langsung menggunakan kuesioner, sedangkan data sekunder diperoleh dari lembaga/instansi terkait serta literatur yang berhubungan dengan penelitian. Metode yang digunakan dalam penelitian ini adalah metode analisis deskriptif (Nazir, 2014). Analisis deskriptif kualitatif digunakan untuk mengetahui persepsi petani padi terhadap program billing system.

\section{HASIL DAN PEMBAHASAN}

\section{A. Keadaan Umum Responden}

Berdasarkan hasil penelitian yang telah dilakukan, rata-rata luas lahan petani padi peserta program billing system yaitu 0,26 ha. Kepemilikan lahan di daerah penelitian masih dalam kategori sempit. Dilihat dari rata-rata umur petani padi peserta program billing system adalah 54 tahun. Mantra (2004) menjelaskan bahwa umur produktif seseorang berada pada kisaran 15-64 tahun. Hal ini menandakan bahwa sebagian besar petani padi peserta program billing system masih dalam dalam umur produktif. Produktifnya umur petani diharapkan mampu mempengaruhi kegiatan usahataninya yang efisien dan menguntungkan. Sebagian besar rata-rata pendidikan petani peserta program billing system adalah tamatan SMP. Tingkat pendidikan dilihat dari pendidikan formal seseorang 
dari jumlah tahun sukses lamanya responden mengikuti pendidikan formal. Tingkat pendidikan seseorang petani juga dapat mempengaruhi keberhasilan usahatani. Dalam hal ini penyerapan informaasi perkembangan teknologi informasi mudah dipahami.

\section{B. Persepsi Petani Padi Terhadap Program Billing System}

Berdasarkan hasil pengamatan, persepsi petani terhadap program billing system merupakan proses pemahaman makna dalam memberikan nilai atas suatu informasi terhadap peristiwa dalam objek yang terdiri dari beberapa indikator penilaian objek yang diamati, yaitu dalam segi tujuan program, pelaksanaan program, dan manfaat program.

\section{Persepsi Petani Padi Terhadap Program Billing System Berdasarkan Tujuan Program}

Persepsi petani terhadap program billing system dilihat dari tujuan program dalam kategori baik. Hal ini dikarenakan petani beranggapan bahwa semua program yang diberikan oleh pemerintah adalah program yang diorientasikan dan bertujuan untuk kepentingan masyarakat (petani). Berdasarkan pertanyaan yang telah diajukan terkait tentang indikator penilaian dari segi tujuan program sebagian besar petani telah mengetahui tujuan dari program billing system tersebut. Petani peserta program billing system menyatakan bahwa tujuan dari program tersebut sangat baik, yaitu membantu petani untuk memperoleh pupuk tepat waktu ketika dibutuhkan, jenis pupuk yang datang lengkap, kualitas mutu yang tidak diragukan, harga lebih murah, dan tempat untuk memperolehnya jelas dan lebih dekat. Akan tetapi dalam proses pelaksanaannya, program billing system tidak semudah apa yang dibayangkan.

\section{Persepsi Petani Padi Terhadap Program Billing System Berdasarkan Pelaksanaan Program}

Persepsi petani terhadap program billing system dilihat dari pelaksanaan program masih dalam kategori kurang baik. Artinya petani menilai bahwa pelaksanaan program billing system kurang diterima oleh petani. Hal ini dikarenakan banyak faktor kelemahan dalam program tersebut. Adapun kelemahan dalam program billing sistem ini dapat dilihat pada Tabel 1. 
Tabel 1. Persepsi Petani Terhadap Program Billing System Dilihat dari Pelaksanaan Program

\begin{tabular}{|c|c|c|}
\hline No & Komponen & Keterangan \\
\hline 1 & $\begin{array}{l}\text { Fasilitas } \\
\text { Teknologi dan } \\
\text { Pelayanan } \\
\text { Infrastruktur }\end{array}$ & $\begin{array}{l}\text { 1. Tidak ada fasilitas komputer tersedia di kelompok tani } \\
\text { 2. Tidak ada fasilitas internet untuk terhubung ke sistem online } \\
\text { 3. Jarak bank untuk melakukan transaksi sulit di jangkau karena } \\
\text { relatif jauh } \\
\text { 4. Tidak ada spesialisasi pelayanan khusus dari pihak bank untuk } \\
\text { melayani peserta anggota program billing system } \\
\text { 5. Akses bank untuk pembayaran sulit butuh waktu untuk } \\
\text { mengantri }\end{array}$ \\
\hline 2 & $\begin{array}{l}\text { Sumber Daya } \\
\text { Manusia }\end{array}$ & $\begin{array}{l}\text { 1. Petani sulit memahami sistem yang digunakan, seperti belum } \\
\text { mampu menggunakan teknologi, kesalahan penginputan data } \\
\text { online, kesalahan transfer uang, kesalahan lupa id/ password } \\
\text { untuk login } \\
\text { 2. Kurang nya sosialisasi terkait program billing system } \\
\text { 3. Kurangnya pelatihan dalam penggunaan program billing } \\
\text { system }\end{array}$ \\
\hline 3 & $\begin{array}{l}\text { Prosedur dan } \\
\text { Peraturan }\end{array}$ & $\begin{array}{l}\text { 1. Prosedur penebusan pupuk terlalu panjang alurnya } \\
\text { 2. Alokasi pupuk yang datang tidak sesuai dengan RDKK yang } \\
\text { diajukan karena sesuai dengan uang yang ditebus/disetor oleh } \\
\text { petani } \\
\text { 3. Petani harus mentransfer uang terlebih dahulu baru } \\
\text { memperoleh alokasi pupuk yang diminta } \\
\text { 4. Input data pupuk satuannya harus bulat } \\
\text { 5. Tidak tepat waktu ketika pupuk dibutuhkan } \\
\text { 6. Penebusan pupuk dengan satuan sak } \\
\text { 7. Penebusan pupuk tidak boleh melebihi RDKK yang diajukan }\end{array}$ \\
\hline
\end{tabular}

Tabel 1 dapat dijelaskan bahwa kelemahan terbesar pada program billing system yang sulit diterima oleh petani adalah pada komponen fasilitas penunjang teknologi dan pelayanan infrastruktur. Pertama, tidak ada fasilitas komputer tersedia di kelompok tani yang akan digunakan petani dalam penginputan data dalam penyusunan RDKK sebagai syarat untuk memperoleh alokasi jatah pupuk. Selain itu, juga berdasarkan hasil wawancara dari beberapa petani padi program billing system, keterampilaan dan pengetahuan dalam penggunaan teknologi masih rendah bahkan petani enggan untuk menggunakannya meskipun komputer telah disediakan oleh pihak pemerintah. Hal ini dikarenakan petani beranggapan bahwa untuk memahami dan menjalankan komputer tersebut butuh waktu cukup lama dan akan menyita waktu petani dalam kegiatan usahataninya. Kedua, tidak ada fasilitas internet untuk terhubung ke sistem online. Dalam hal ini akan menyulitkan 
petani untuk mengakses pengiriman data pengajuan RDKK ke sistem. Fasilitas komputer dan internet dalam hal ini saling keterkaitan guna mendukung proses pelaksanaan program billing system.

Ketiga, jarak bank untuk melakukan transaksi sulit dijangkau karena relatif jauh. Proses pelaksanaan program billing system perlu melakukan konfirmasi terkait pengiriman berkas secara online dan perlu melakukan transaksi pembayaran setoran pembelian pupuk program billing system jadi terhambat dan masih dibutuhkan biaya transportasi untuk menuju lokasi tersebut. Keempat, tidak ada spesialisasi pelayanan khusus dari pihak bank untuk melayani peserta anggota program billing system dan akses bank untuk pembayaran sulit dan butuh waktu untuk mengantri.

Kelemahan program billing system selanjutnya terletak pada komponen sumberdaya manusianya. Sumberdaya manusia merupakan komponen aspek penting yang menjadi peran dalam pencapaian dan keberhasilan suatu program. Pertama, terletak pada petani yang sulit untuk memahami sistem yang digunakan, seperti belum mampu menggunakan teknologi, kesalahan penginputan data online, kesalahan transfer uang, kesalahan lupa id/ password untuk login. Kedua, kurang nya sosialisasi terkait program billing system yang berdampak pada minimnya pengetahuaan terkait sistem dan perkembangan informasi program yang berjalan. Ketiga, kurangnya pelatihan dalam penggunaan program billing system. Pihak-pihak yang terkait dalam tim program billing system dari pemerintah yang mencanangkan program tersebut hanya satu kali memberikan pelatihan.

Prosedur dan peraturan dalam program billing system menjadi salah satu aspek/komponen yang menjadi kelemahan program tersebut. Berdasarkan hasil penelitian, menurut petani peserta program billing system bahwa prosedur penebusan pupuk terlalu panjang alurnya. Dibandingkan dengan sistem penebusan pupuk sebelum billing system, petani hanya menyiapkan RDKK lalu memberikan kepada pihak petugas penyuluh lapangan. Sedangkan saat ini adanya program billing system, petani harus melewati beberapa prosedur hingga sampai mendapatkan pupuk tersebut. Alokasi pupuk yang datang tidak sesuai dengan RDKK yang diajukan karena sesuai dengan uang yang ditebus/disetor oleh petani sehingga petani sulit 


\section{PERSEPSI PETANI PADI TERHADAP PROGRAM BILLING SYSTEM \\ DI KECAMATAN METRO BARAT KOTA METRO \\ Muher Sukmayanto, Erika Dwi Alviana, Abdul Muhtholib}

memperoleh kekurangan pupuk yang diminta. Selanjutnya petani yang tergabung dalam peserta program billing system harus mentransfer uang terlebih dahulu baru memperoleh alokasi pupuk yang diminta. Petani mengalami kesulitan dalam pengadaan modal uang untuk menyetorkan ke pihak bank karena modal terkadang terpakai untuk kebutuhan sehari-hari. Penginputan data pupuk satuannya harus bulat, maksudnya adalah jika petani yang memiliki lahan sempit yang kebutuhan pupuknya sedikit membuat petani kelebihan pupuk yang diterima. Kelemahan lainnya dalam aspek prosedur yaitu pada kedatangan pupuk yang tidak tepat waktu yang berdampak buruk terhadap berlangsungnya usahatani. Contohnya pada usia padi tertentu diperlukan perlakuaan pupuk untuk proses pertumbuhan padi, jika tidak diberikan pada waktu tersebut akan berdampak terganggunya proses pertumbuhan padi. Selain itu, petani dalam penebusan pupuk harus dengan satuan sak dan tidak boleh melebihi RDKK yang diajukan.

Persepsi petani terhadap program billing system dilihat dari manfaat yang diperoleh tergolong dalam kategori baik. Manfaat bagi petani yang dirasakan nyata dari hasil penelitian berupa keakraban antar petani yang lebih meningkat dikarenakan sering terjalinnya pertemuan koordinasi antar anggota petani meningkat. Selain itu, meningkatkan kesadaran petani untuk membuat RDKK pupuk bersubsidi bersama-sama. Dengan adanya billing system membantu petani untuk menghasilkan padi berkualitas karena jenis pupuk yang disediakan lengkap sesuai dengan kebutuhan petani. Adanya billing system membantu meningkatkan hasil produksi padi, membantu petani meningkatkan pendapatan karena harga pupuk subsidi dari pemerintah yang diterima petani relatif murah. Menurut Rani, Elly, dan Gema (2018), stabilitas harga dapat merangsang petani untuk meningkatkan produksi dan kualitas hasil. Manfaat lainnya bagi petani adalah meningkatnya pengetahuan dan keterampilan. Selain itu, pertemuan petani dalam koordinasi berdampak positif berupa pertukaran informasi yang juga berpengaruh terhadap pengetahuan dan keterampilan usahatani.

\section{KESIMPULAN}

Persepsi petani terhadap program billing system dilihat dari tujuan program dalam kategori baik karena petani beranggapan bahwa semua program yang 
diberikan oleh pemerintah adalah program yang diorientasikan dan bertujuan untuk kepentingan masyarakat (petani).

Persepsi petani terhadap program billing system dilihat dari pelaksanaan program masih dalam kategori kurang baik karena petani menilai bahwa pelaksanaan program billing system kurang diterima oleh petani. Hal ini dikarenakan banyak faktor kelemahan dalam program tersebut. Adapun kelemahan dalam program billing system adalah kurangnya fasilitas teknologi dan pelayanan infrastruktur, sumberdaya manusia yang kurang diperhatikan, prosedur dan peraturan yang terlalu rumit.

Persepsi petani terhadap program billing system dilihat dari manfaat yang diperoleh petani tergolong dalam kategori baik. Hal ini karena meningkatnya keakraban antar petani, meningkatnya hasil produksi padi, pendapatan petani, dan meningkatnya pengetahuan dan keterampilan petani.

\section{DAFTAR PUSTAKA}

Dewanto, F.G., J.J.M.F. Londok, R.A.F. Tuturoong, dan W.B. Kaunang. 2013. Pengaruh pemukan anorganik dan organik terhadap produksi tanaman jagung sebagai sumber pakan. Jurnal Zootek (Zootek Journal) 32(5):1-8.

Fachrista, I.A. dan Sarwedah, M. 2014. Persepsi dan Tingkat Adopsi Petani Terhadap Inovasi Teknologi Pengelolaan Tanaman Terpadu Padi Sawah. Agriekonomika; Jurnal Sosial Ekonomi dan Kebijakan Pertanian 3(1): 1-10.

Juliandi A., Irfan. dan Manurung, S. 2014. Metodologi Penelitian Bisnis: Konsep dan Aplikasi. Medan: UMSU Press.

Mantra, I.B. 2004. Demografi Umum. Yogyakarta: Penerbit Pustaka Pelajar.

Nazir. 2014. Metode Penelitian. Bogor: Ghalia Indonesia

Peraturan Menteri Perdagangan RI. 2011. Pengadaan dan Penyaluran Pupuk Bersubsidi Untuk Sektor Pertanian. http://www.kemendag.go.id/files/re gulasi/2011/06/Pupuk1.pdf. Diakses 12 November 2018.

Rani, A.B.K., Elly, R., Gema, W.M., 2018. Perilaku Petani dalam Usahatani Mangga di Kabupaten Cirebon. Jurnal Pemikiran Masyarakat Ilmiah Berwawasan Agribisnis 4(2): 197-209.

Sahabat Petani. 2018. Billing System, Strategi Pemprov Lampung Perbaiki Distribusi Pupuk Bersubsidi.

http://sahabatpetani.com/2018/05/3 1/billing-system-strategi-pemprovlampung-perbaiki-distribusi-pupukbersubsidi/. Diakses 12 November 2018.

Suara Pedia. 2018. Program Billing System pupuk bersubsidi untungkan petani. http://suarapedia.com/id7346-post-program-billing-systempupuk-bersubsidi-untungkanpetani.html. Diakses 12 November 2018.

Sugiarto, F. 2017. Pedoman Pelaksanaan Penyediaan dan Peyaluran Pupuk 


\section{PERSEPSI PETANI PADI TERHADAP PROGRAM BILLING SYSTEM \\ DI KECAMATAN METRO BARAT KOTA METRO \\ Muher Sukmayanto, Erika Dwi Alviana, Abdul Muhtholib}

Bersubsidi TA 2016. https://docplayer.info/32149861Pedoman-pelaksanaan-penyediaandan-penyaluran-pupuk-bersubsidita-2016.html. Diakses November 2018.
Sugiyono. 2010. Metode Penelitian Pendidikan Pendekatan Kuantitatif, kualitatif, dan $R \& D$. Bandung: Alfabeta.

Alfabeta. 